\title{
The Strategic Role of Lean - A Discussion
}

\author{
Gabriela Lobo Veiga \\ Pontifícia Universidade Católica do Paraná (PUCPR), Curitiba, PR, Brazil \\ Edson Pinheiro de Lima \\ Pontifícia Universidade Católica do Paraná (PUCPR), Curitiba, PR, Brazil \\ Universidade Tecnológica Federal do Paraná (UTFPR), Curitiba, PR, Brazil
}

\author{
Jannis Jan Angelis \\ Warwick Business School, University of Warwick, UK
}

Sergio Eduardo Gouvea da Costa

Pontifícia Universidade Católica do Paraná (PUCPR), Curitiba, PR, Brazil

Universidade Tecnológica Federal do Paraná (UTFPR), Curitiba, PR, Brazil

\begin{abstract}
Operations strategy and its development have received a lot of attention in the operations management literature. However, literature related to benefits of improvement programs, such as lean production, is often contradictory to operations strategy principles. There is a large body of work arguing that lean can bring substantial performance improvements, indicating that operations strategy formalization might be unnecessary when certain operational processes improvements are applied. However, some literature emphasize the importance of operations strategy, stating that its formulation leads to superior competitiveness when lean techniques are properly related to competitive dimensions and to decision areas. In this study, a comprehensive literature review has been carried out to reveal insights on both streams of study and it is used to conceive a framework and a research interview protocol based on that. Hence, this study compares experts' view of the strategic role of lean. Such a comparison is done through a range of interviews. The results support the notion that lean can generate a strong advantage in many competitive dimensions; even so, a formal strategy approach is still necessary to focus lean model implementation.
\end{abstract}

Keywords: Lean, Operations strategy, Competitive dimensions, Decision areas.

\section{Introduction}

In operations management lean production can be considered an approach for designing and implementing operations strategy (Veiga, 2009; Berry et al., 2007; Sánchez and Pérez, 2001). There is a large body of work arguing that lean can bring a significant performance improvement in more than one competitive dimension (Hayes and Pisano, 1994; Flynn et al., 1999; Sweeney, 1991). Such a stream of literature 
could controvert the necessity of an operations strategy. Other research emphasizes the importance of operations strategy and that its formulation leads to superior competitiveness (Thun, 2008). Hence, operations or manufacturing strategy affords performance improvements in organizational management (Leong and Ward, 1995). To explore the issue further, this study covers a relevant literature review. For further insights experts on both lean and operations strategy were asked about lean contribution to competitive priorities, that is, figuring lean approach to strategy and lean support to capabilities development.

This paper is structured as follows. First, a theoretical review identifies different focus regarding lean as an operations strategy. The study then explores expert views on lean manufacturing strategic role. This is consolidated in a set of summarizing statements, which contribute to reduce the misunderstanding between both streams of literature.

\section{Operations Strategy}

Competitive priorities are key variables that define organizations' strategic focus, particularly on developing capabilities that may enhance long term competitive positioning. The priorities are found in decision making on areas such as capacity, facilities, equipment and process technologies, vertical integration, human resources, quality system etc (Smith and Reece, 1999; Platts and Gregory, 1990; Leong et al., 1990). Operations strategy matches these competitive dimensions and decision areas, translating market requirements into operations strategic decisions as well as exploring operations resources capabilities in the chosen markets (Acur et al., 2003; Leong et al., 1990). As such, operations strategy deploys business strategies and leverages production functions to achieve established long term competitive objectives (Amoako-Gyampaha and Boye, 2001).

Studies focusing on the operations strategy alignment or fit can be classified as approaches that are internal, external or a combination of both. Market based approaches translate market requirements into operations strategy content (Lewis and Slack, 2002). A resource based perspective is taken when new strategic options naturally emerge from organisation resources mobilization and use (Wernerfelt, 1984). Lewis and Slack (2002) argue that operations strategies must assure that production resources are being used to bring competitive advantages to the companies. Hayes and Wheelwright (1985) described a four stages model, showing how manufacturing's strategic role could evolve over time.

Following Lewis and Slack (2002), the internal and external approaches can be linked with short and long term strategy perspectives, whereby operations strategy is related to internal and external requirements reconciliation. External requirements derive from markets demand and internal requirements originate in operational resource mobilization, integration and use. Brown and Blackmon (2005) support the integration of both approaches as manufacturing strategy is being designed, implemented and managed. Market requirements and manufacturing capabilities can be matched following competitive priorities in a dynamic and unpredictable market in order to sustain high levels of competitive performance.

\section{Lean as a Production Management Philosophy}

Research on lean is oriented to the study of both its techniques and philosophies or principles. A significant number of studies address the use of lean 
tools and techniques, approaching them in a world-widely operations perspective (Schonberger, 2007; Bhasin and Burcher, 2006). Recently there has been a growing debate about the role of lean culture for the success of lean implementation (Steward and Raman, 2007; Bhasin and Burcher, 2006; Achanga et al., 2006; Spear, 2004; Spear and Bowen, 1999; Womack et al., 1996). However, in practice, companies tend to focus mainly on training people in the use of tools and techniques, giving little attention to understand the human factors involved and to build an appropriate culture in the lean implementations (Dahlgaard and Dahlgaard-park, 2006).

There is a body of academic studies on elementary capabilities that if developed may encourage cultural change (Hayes and Pisano, 1994). Spear and Bowen (1999), in depicting the core elements of Toyota, propose that the key point is taking every improvement opportunity as a scientific experiment. Four rules that capture tacit knowledge embedded in its production system are proposed: high levels of work standardization; direct connection between every costumer-supplier; direct and simple pathways for every product or service; and improvement implementation according to scientific methods. Spear's (2004) paper complements this work, reporting on the management training process of an upper-level position in Toyota in the US. According to Towill et al. (2007), waste reduction is only one of many lean tools and principles, such as task control, pathways elimination and improvement activities. Moreover, Adler (1993) describes standardization as encouraging organisational learning and therefore continuous improvement.

The Toyota Way, which reflects the beliefs and methods of the Toyota Production System developed since 1935 also emphasize human factors in its production management model. It was formally systematized and documented in 2001 for training purposes due the growing numbers of lean adopting companies' outside Japan (Fishman, 2007; Holweg, 2006). As people are considered a strategic factor for lean adoption, investments in their development are necessary to improve companies' capabilities in lean production management (Achanga et al., 2006; Spear and Bowen, 1999). To do so, financial capabilities are singled out as an important factor to staff training and specialized hiring services (Achanga et al., 2006). Human assets are also exploited in work condition improvements (Conti et al., 2006; Saurin and Ferreira, 2009). One approach adopted to challenge people is the establishment of tough goals, which increases workers' consciousness and self-worth. (Takeuchi et al., 2008). Empowerment is also identified by Dahlgaard and Dahlgaard-Park (2006) as a key factor in human resources development. Achanga et al. (2006) explored critical factors in lean implementation within SME's and the role of leadership. Sim and Rogers (2009) also mention the lack of committed leadership as a barrier to implement lean.

In accordance with Liker (2006), constancy of purpose is essential in lean philosophy. According to a report by Fishman (2007), Toyota employs a principle of current situation non-acceptance, which is an essential element for encouraging continuous improvement and generating innovative ideas. The author remarks that the existence of this culture raises the workers' concern for producing goods more effectively each day and educates everybody to do so, because they are constantly thinking about how to do this.

Lean adopts an incremental approach for process improvement and radical changes are built over time as a result of consistent small steps (Smeds, 1994). In some 
situations when it is necessary to develop new knowledge and to overcome performance barriers it may even be preferable to change the system rather than improve it. In contrast to the traditional approach, which is oriented to the optimization of an established system (Clark, 1996). May (2007) states that innovation is the biggest Toyota's source of competitive advantage.

There is also a wide amount of literature discussing the relationship between leanness and agility. And it could be concluded that the approaches are complementary since lean focus on customer satisfaction (Ohno, 1997; Liker, 2006) and agility is related to the interface between organization and market needs. In this sense the agile capabilities are: delivering value to costumer, being ready for change, valuing human knowledge and skills and forming virtual partnerships (Katayama and Bennett, 1999). Although they are complementary concepts it is important to highlight that pursuit agility might presume leanness, but pursuit leanness maybe not presume agility. Agile manufacturing focus on attending efficiently changes on operating states in response to volatile market place (Narasimham et al., 2006; Naylor et al., 1999) and lean focus on creating a stability through a JIT flow, to guarantee a level schedule (Shah and Ward, 2003; Naylor et al., 1999).

Table 1 shows some lean principles that could be used to identify basic lean capabilities that a company should develop. Some bibliographies support each principle, as follows.

Having identified lean capabilities, their employment in the implementation process is discussed next.

\section{Using Trade-offs in Lean Implementation}

The traditional trade-off definition indicates that raising one competitive dimension may decrease another (Porter, 1996; Slack, 1993; Skinner, 1974). However, some literature has been approaching processes improvement in a cumulative capability development way, as a method for trade-off compensation (De Toni and Tonchia, 2002; Flynn et al., 1999). Silveira (2005) summarizes three major ideas regarding trade-offs concept from operations management literature. First, the influence of tradeoffs in manufacturing operations seems to be contingent to manufacturing strategy and production structure. Second, trade-offs are dynamic and highly influenced by managerial action. Also, trade-offs can be managed in long term, through continuous initiatives in manufacturing capabilities development and strategy updating. These seems to indicate that trade-offs can be improved or overcome. It can be argued that lean may bring significant performance improvements to several competitive dimensions. For example, companies employing lean may achieve higher quality, lower costs, greater flexibility, faster product development and production, all dimensions which are managed at the same time (Flynn et al., 1999; Hayes and Pisano, 1994; Sweeney, 1991).

According to Slack (2005), misalignment between manufacturing and business can be blamed on two misconceptions: that manufacturing is able to do everything, and that manufacturing contributes to efficiency achievement, not directly contributing for the effective market needs achievement. Porter (1996) supports both arguments, stating that operational efficiency is not sufficient to provide sustainability. It is also necessary to outperform competitors in some key aspect. Berry et al. (2007) recognize 
that not all factors are equally important for all kinds of performance improvement, and Boyer and Lewis (2002) have tested the trade-off model in a survey with data gathered from 110 plants. Their findings support the necessity of trade-offs identification and management. However, there are subtle differences between competitive priorities across organisations as well as in their different hierarchy levels. Managers had been trying to eliminate trade-offs through production processes improvement. But without trade-offs companies are not able to achieve a sustainable competitive advantage, since they create the need for choice and differentiation, without which any idea may be emulated (Porter, 1996). Trade-offs stimulate differentiation, while operations strategy

Table 1. Lean capabilities.

\begin{tabular}{|c|c|}
\hline Principle & Source \\
\hline Seeing things firsthand & Liker (2006); Ohno (1997) \\
\hline Having constancy of purpose & Liker (2006) \\
\hline Imputing contradictory viewpoints & Takeuchi et al. (2008) \\
\hline Establishing tough goals & Takeuchi et al. (2008) \\
\hline $\begin{array}{c}\text { Taking improvements opportunities } \\
\text { as scientific experiments }\end{array}$ & Spear and Bowen (1999) \\
\hline Specifying all work & Spear and Bowen (1999), Adler (1993) \\
\hline $\begin{array}{c}\text { Creating direct connection between } \\
\text { every costumer and supplier, }\end{array}$ & $\begin{array}{c}\text { Dahlgaard and Dahlgaard-park (2006), } \\
\text { Spear and Bowen (1999) }\end{array}$ \\
\hline partnership in every relationship & Liker (2006), Spear and Bowen (1999), \\
\hline Respecting & Katayama and Bennett (1999) \\
\hline piving responsibility to & Dahlgaard and Dahlgaard-Park (2006), \\
Spear (2004), Adler (1993)
\end{tabular}


seeks in developing operational competence which is necessary to overcome tradeoffs. The competitive pressures require a high level of coherence and consistency among strategy, actions and performance (Laugen et al., 2005).

In their study, Ahmed and Montagno (1996) assess the relationship between strategy and performance, showing that organisations have higher performance when they are formally managing operations strategy. Similarly, Acur et al. (2003) studied the influence of formalizing manufacturing strategy. Their analysis show that in companies with formal strategy competitive priorities definition, improvement goals and action programs are significantly better aligned than in companies without them. It is also important to clarify causal relationships between strategic directives, actions and results, allowing commitment to strategy and therefore pursuing the intended objectives. Therefore, both approaches regarding competitive or performance dimensions management could be complementary when pursuing long term benefits (Steward and Raman, 2007; Liker, 2006; Bhasin and Burcher, 2006; Lewis, 2000; Clark, 1996).

Despite the potential for lean to generate positive results in more than one dimension, strategies based on lean or improvement initiatives often do not contribute to sustain competitive position neither to enhance long term sustainability (Corbett and Campbell-Hunt, 2002). Hence, focusing on a few competitive priorities can be an important aspect for successful use of lean. For this, it is important to get the right balance to lean actions to support lean culture dissemination throughout the organization. Note that few, if indeed any, companies have been successful in achieving the benefit of lean to rival Toyota. This failure in driving value from lean may be due the focus of tools and techniques application rather than conceiving a model that integrates processes, methodologies, techniques and tools. Indeed, to succeed in implementing lean it is necessary to promote a cultural change, and to do so a long term perspective may well be required which increases the importance of a strategic approach to lean employment.

It is recognized that a strategic approach helps in explaining organisational performance and the necessary practices to achieve lean implementation and improve operational performance (Takeuchi et al., 2008; Towill et al., 2007; Berry et al., 2007; Liker, 2006; Bhasin and Burcher, 2006; Womack et al., 1996; Smeds, 1994). Generally, two arguments are founded in literature defending the necessity of a strategic approach for lean implementation. First, the logical path definition for achieving long term objectives (Amoako-Gyampaha and Boye, 2001; Smith and Reece, 1999; Platts and Gregory, 1990; Leong et al., 1990). This argument states that it is necessary define a focus to choose complementary alternatives and get consistency over the time. Second, manufacturing vision building through key capabilities, which allows competitive sustainability achievement (Clark, 1996; Hayes and Pisano, 1994). This argument states that it is important to identify key capabilities to support the achievement of long term objectives.

Studies about lean philosophy generally claim that lean can bring significant competitive advantage when it is exploited in the long term (Bhasin and Burcher, 2006; Sun and Hong, 2002; Lewis, 2000) for the development of specific capabilities. (Clark, 1996; Leong and Ward, 1995). As remarked by Corbett and Campbell-Hunt (2002), the development of distinctive manufacturing capabilities such as improvement programs 
should be made in accordance to the competitive priorities in order to bring a positive operations result over long term.

\section{Proposed Framework}

The previous theoretical review supported the framework development. It is grounded on a combination of practices and philosophy, and it establishes a relationship between these elements and key operations strategy concepts as competitive priorities and capabilities. The relation between lean practices and competitive priorities is made in order to translate the alignment between operations and business levels. Then, lean philosophy realization takes place to guarantee the development of capabilities, which strongly influence the ability to implement cultural change.

The framework covers two parts: external and internal. The external analysis focuses on the match between operations processes and manufacturing strategy. The internal analysis investigates the firm capacity to generate lean capabilities that are used to sustain lean philosophy and strategy development (Veiga et al., 2009). development.

This briefly definition of lean strategic role will guide the interviews

\section{Research Method}

Based on a comprehensive literature review it was possible to bring out the framework presented in Figure 1. Then some interviews were conducted to refine the proposed model. For this reason the academic background combined with practical experience of interviewees was an important criteria for their selection.

For the study, nine UK experts with background and research interest on operations strategy, service excellence, performance management, strategic planning, lean and agile operations were interviewed. They were selected due to their expertise on implementing lean systems and on researching it. Their respective profiles are described in Table 2.

The interviews covered relationship among concepts identified in the literature and proposed in the framework shown in Figure 1. The interviewees were questioned about several identified concepts and relationships, as seen in Figure 1. The interviews were primarily semi-structured to better capture their knowledge and insights (Yin, 2001). Questions covered the strategic role of lean implementation and were related to competitive requirements alignment, manufacturing capabilities exploitation and the adopted strategic approach when using lean. The questions were:

\begin{tabular}{|c|c|}
\hline \multicolumn{2}{|c|}{ Fit between practices and priorities (external approach) } \\
\hline Practices \\
\hline Competitive priorities \\
\hline Philosophy \\
\hline Cxploration of flean production capabilities (internal approach) \\
\hline
\end{tabular}

Figure 1. Lean relation within operations strategy. 
Table 2. Interviewees profile.

\begin{tabular}{|c|c|c|c|}
\hline $\begin{array}{c}\text { Professional } \\
\text { activity }\end{array}$ & $\begin{array}{l}\text { Educational } \\
\text { background }\end{array}$ & $\begin{array}{l}\text { Research } \\
\text { interests }\end{array}$ & Expertise \\
\hline $\begin{array}{l}\text { (I1) Associate } \\
\text { Professor of } \\
\text { Operations } \\
\text { Management }\end{array}$ & $\begin{array}{l}\text { MSc (LiU, Sweden), } \\
\text { PhD (Cambridge), } \\
\text { BEng (UTM) }\end{array}$ & $\begin{array}{l}\text { Operations strategy, } \\
\text { performance } \\
\text { measurement, } \\
\text { decision support } \\
\text { system, technology } \\
\text { management, service } \\
\text { operations and lean } \\
\text { management. }\end{array}$ & $\begin{array}{l}\text { Managerial position in a } \\
\text { range of organisations in } \\
\text { Asia, including Shell, NEC, } \\
\text { BAT, and Guthrie. Main } \\
\text { responsibility on operations } \\
\text { and process improvement } \\
\text { Expertise on projects on } \\
\text { strategic investment decisions, } \\
\text { strategy decision modeling, } \\
\text { performance measurements } \\
\text { systems. }\end{array}$ \\
\hline $\begin{array}{l}\text { (I2) Assistant } \\
\text { Professor of } \\
\text { Operations } \\
\text { Management }\end{array}$ & $\begin{array}{l}\text { BA (Stockholm and } \\
\text { Lund Universities), } \\
\text { BA (Stockholm), MA } \\
\text { (SOAS, University } \\
\text { of London), Mphil } \\
\text { (Cambridge), } \\
\text { MsocSc (Stockholm), } \\
\text { PGCPCE(HE) } \\
\text { (Warwick), PhD } \\
\text { (Cambridge), BSSc } \\
\text { (Stockholm and } \\
\text { Uppsala Universities) }\end{array}$ & $\begin{array}{c}\text { Operations } \\
\text { strategy, Lean and } \\
\text { agile operations, } \\
\text { Behavioural } \\
\text { operations, Supply } \\
\text { chain sustainability } \\
\text { and risk, Health } \\
\text { service improvements. }\end{array}$ & $\begin{array}{c}\text { Experience on venture } \\
\text { capital advisory and industry } \\
\text { consulting. }\end{array}$ \\
\hline $\begin{array}{l}\text { (I3) Professor in } \\
\text { Supply Strategy }\end{array}$ & Meng, $\mathrm{PhD}$ & $\begin{array}{l}\text { Strategic benefits of } \\
\text { operational and supply } \\
\text { competence, Dis- } \\
\text { benefits of operational } \\
\text { and supply failure }\end{array}$ & $\begin{array}{l}\text { Consultancy on a range of } \\
\text { private and public sector } \\
\text { rganizations in the UK } \\
\text { and the rest of Europe, } \\
\text { including: Volvo, Unilever, } \\
\text { Mars Confectionery, } \\
\text { Severn Trent Water, British } \\
\text { Telecommunications, Coats- } \\
\text { Viyella, ICI Paints, Jones Lang } \\
\text { Lasalle, Alfa Laval, Morgan } \\
\text { Stanley, UBS and Zurich } \\
\text { Financial Services. }\end{array}$ \\
\hline $\begin{array}{l}\text { (I4) Professor } \\
\text { of Strategic } \\
\text { Manufacture }\end{array}$ & $\begin{array}{l}\text { PhD (Cranfield } \\
\text { University), } \\
\text { MSc (Cranfield } \\
\text { University) }\end{array}$ & $\begin{array}{l}\text { Manufacturing } \\
\text { Strategy Practices } \\
\text { (eg: Agile, Lean, } \\
\text { Mass Customisation, } \\
\text { Project, Total Service } \\
\text { Manufacture) and } \\
\text { formulation processes. } \\
\text { Strategic positioning } \\
\text { processes (eg: Make/ } \\
\text { buy, Outsourcing and } \\
\text { Offshoring) }\end{array}$ & $\begin{array}{l}\text { Sixteen years of experience } \\
\text { in management and } \\
\text { engineering, working with } \\
\text { the leading companies in his } \\
\text { field including Rolls-Royce, } \\
\text { Caterpillar, Alstom, MAN and } \\
\text { Xerox. } \\
\text { Working close to industry } \\
\text { and winning projects with a } \\
\text { combined value in excess of } \\
\text { several million pounds. }\end{array}$ \\
\hline
\end{tabular}


Table 2. Continued....

\begin{tabular}{|c|c|c|c|}
\hline $\begin{array}{c}\text { Professional } \\
\text { activity }\end{array}$ & $\begin{array}{l}\text { Educational } \\
\text { background }\end{array}$ & $\begin{array}{l}\text { Research } \\
\text { interests }\end{array}$ & Expertise \\
\hline $\begin{array}{l}\text { (I5) Vice } \\
\text { president of } \\
\text { the Institute } \\
\text { of Customer } \\
\text { Service, } \\
\text { Professor of } \\
\text { Operations } \\
\text { Management }\end{array}$ & $\begin{array}{l}\text { Sc (Aston), PGCE } \\
\text { (Lancaster), PhD } \\
\text { (Warwick) }\end{array}$ & $\begin{array}{c}\text { Service } \\
\text { transformation, } \\
\text { service excellence, } \\
\text { customer service, } \\
\text { service design, service } \\
\text { recovery, complaint } \\
\text { management, } \\
\text { and performance } \\
\text { management. }\end{array}$ & $\begin{array}{l}\text { Twenty years of experience } \\
\text { managing several line } \\
\text { management and senior } \\
\text { management posts in a number } \\
\text { of service organisations in } \\
\text { both the public and private } \\
\text { sectors. }\end{array}$ \\
\hline $\begin{array}{l}\text { (I6) Associate } \\
\text { Professor of } \\
\text { Operations } \\
\text { Management. } \\
\text { Adviser of } \\
\text { a number of } \\
\text { boards and } \\
\text { committees for } \\
\text { organisations } \\
\text { such as the Audit } \\
\text { Commission, } \\
\text { Welsh Assembly } \\
\text { Government, } \\
\text { Government } \\
\text { Skills, HMRC, } \\
\text { Local Authorities } \\
\text { and HM Court } \\
\text { Services. }\end{array}$ & $\begin{array}{l}\text { BEng (Nottingham), } \\
\text { MSc (Cranfield), } \\
\text { PhD (UMIST) }\end{array}$ & $\begin{array}{l}\text { Performance } \\
\text { measurement and } \\
\text { management; } \\
\text { improvement and } \\
\text { innovation for both } \\
\text { private and public } \\
\text { sector. }\end{array}$ & $\begin{array}{l}\text { Experience as a project } \\
\text { Manager of a research project } \\
\text { for the Scottish Executive } \\
\text { which evaluated how 'lean' } \\
\text { techniques were and could } \\
\text { be used in the public sector. } \\
\text { Involvement on developing a } \\
\text { Strategic Lean Implementation } \\
\text { Methodology for Hospitals }\end{array}$ \\
\hline $\begin{array}{l}\text { (I7) Advisor } \\
\text { to the NHS } \\
\text { on the design } \\
\text { of healthcare } \\
\text { processes. } \\
\text { Associate } \\
\text { Professor of } \\
\text { Operations } \\
\text { Management }\end{array}$ & $\begin{array}{l}\text { BEng (UMIST), } \\
\text { BSc (UMIST), MBA } \\
\text { (Warwick) }\end{array}$ & $\begin{array}{c}\text { Management of } \\
\text { service technology; } \\
\text { operations strategy; } \\
\text { operations } \\
\text { management in } \\
\text { healthcare. }\end{array}$ & $\begin{array}{l}\text { Experience on redesigning of } \\
\text { emergency treatment processes } \\
\text { and other aspects of hospital } \\
\text { activity. }\end{array}$ \\
\hline $\begin{array}{c}\text { (I8) Senior } \\
\text { Teaching Fellow }\end{array}$ & & $\begin{array}{l}\text { Operations strategy, } \\
\text { supply chain } \\
\text { management }\end{array}$ & $\begin{array}{c}\text { Experience as Sales Manager } \\
\text { and Business Development } \\
\text { Director }\end{array}$ \\
\hline $\begin{array}{l}\text { (19) Assistant } \\
\text { Professor of } \\
\text { Operations } \\
\text { Management. } \\
\text { Member of } \\
\text { the Chartered } \\
\text { Institute of } \\
\text { Purchasing and } \\
\text { Supply (CIPS). }\end{array}$ & $\begin{array}{l}\text { BSc (UCE), MBA } \\
\text { (Birmingham), } \\
\text { MSc (UCE), PhD } \\
\text { (The University of } \\
\text { Birmingham) }\end{array}$ & $\begin{array}{c}\text { Relationship } \\
\text { Management, Supply } \\
\text { Chain Management, } \\
\text { E-Business and } \\
\text { Strategy, Operations } \\
\text { Strategy. }\end{array}$ & $\begin{array}{l}\text { Consultancy on supply } \\
\text { chain management, strategic } \\
\text { sourcing and effective } \\
\text { procurement techniques and } \\
\text { process improvement. }\end{array}$ \\
\hline
\end{tabular}


- Which role does lean take in realizing a specific competitive strategy?

- Which role does lean take in building manufacturing capabilities?

- Operations strategy might have internal focus in capabilities building and external demand accomplishment. How does lean fit with internal and external orientation?

In addition to the semi-structured questions, the relation between lean tools and techniques and their performance impact was obtained by asking interviewees to classify the level of relationship on a Likert scale of 1 (none relation) to 5 (very strong relation) (Rea and Parker, 2002). The competitive priorities were selected according to Slack et al. (1997) approach, adding innovativeness criteria, which have been strongly approached by literature (OCDE, 1997).

\section{Interviews Results and Analysis}

The results were investigated regarding three aspects: lean contribution to strategy; lean capabilities identification and contribution; and balanced strategic approach. Regarding the role of lean in implementing competitive strategy of firms, Interviewee 1 (I1), I2 and I9 claimed that lean employment contributes to various performance dimensions. However, I3 emphasized that the potential of lean can only be fully realised when lean techniques are applied as a bundles and fitting with the organisational context (external and internal contingencies). Meanwhile, I9 and I8 stated that sustainability only can be achieved when lean is implemented in the organisation as a whole and not as isolated efficiency islands.

I5 expressed a more limited view, arguing that despite lean is able to influence any kind of competitive strategy, this impact is sometimes only indirect on some priorities like quality and differentiation. On a similar thought, I9 stated that lean develops quality, speed and dependability while cost and innovativeness are achieved indirectly. Meanwhile, I7 stated that lean can influence most of the strategic objectives, the ones related to cost and quality in early stages of lean implementation and the others when organisation achieve a higher lean maturity. Accordingly, lean contributes to all objectives through cost performance improvements and therefore indirectly affects the others strategic performance dimensions as well.

With a different approach, interviews I4, I5 and I6 claimed that the role of lean on market requirements largely depends on the set competitive strategy. They all agreed that lean provides a noticeable and positive impact in a cost based strategy. However, the impact is less in differentiation based strategies in both frequency and impact. I3 had a similar opinion, stating that the classic objectives related to lean are defined by quality, costs and speed criteria. I2 also supported the quality and costs objectives, adding innovation as new criteria. Meanwhile, interviewees I4 and I5 argued that lean does not provide innovation, which is contradictory to several studies that supports the innovation potential of lean (Yeung et al., 2007; May, 2007; Fishman, 2007; Nonaka and Takeuchi, 1997; Adler, 1993).

Several of the interviewees - I1, I2, I3 and I4 - stated that an organisation's context highly influences lean application. Moreover, I3 added that lean techniques can only bring benefits when implemented in bundles, as stated in Shah and Ward (2003) 
among others. This suggests that the bundle constitution of techniques may bring different performance improvements and therefore impact differently on the strategy.

Figures 2-7 illustrate the interviewees' views on the lean tools and techniques and competitive priorities.

Figure 2 shows that quality is a criteria highly influence by lean tools and techniques, and mainly by root cause analysis, $5 \mathrm{~s}$, standard work, visual management, and the lean office.

Costs, as can be seen in Figure 3, was not classified as greatly influenced by the application of lean tools.

Overall, as seen in Figure 4, speed to market was also not classified as greatly influenced by the application of lean tools.

As can be expected, Figure 5 shows that lean tools carry out a strong influence on dependability, mainly through techniques such as $5 \mathrm{~s}$, standard work and TPM.

Different from stated by some authors (Ohno, 1997) Figure 6 indicate that flexibility was not been viewed as influenced by lean tools.

Figure 7 indicate that innovativeness were not been viewed as influenced by lean most of tools either. There are some specific lean tools designed to generate innovation as product development and suggestion programme.

The interview results show that quality followed closely by dependability are considered the most influenced competitive priority by far. This is expected given

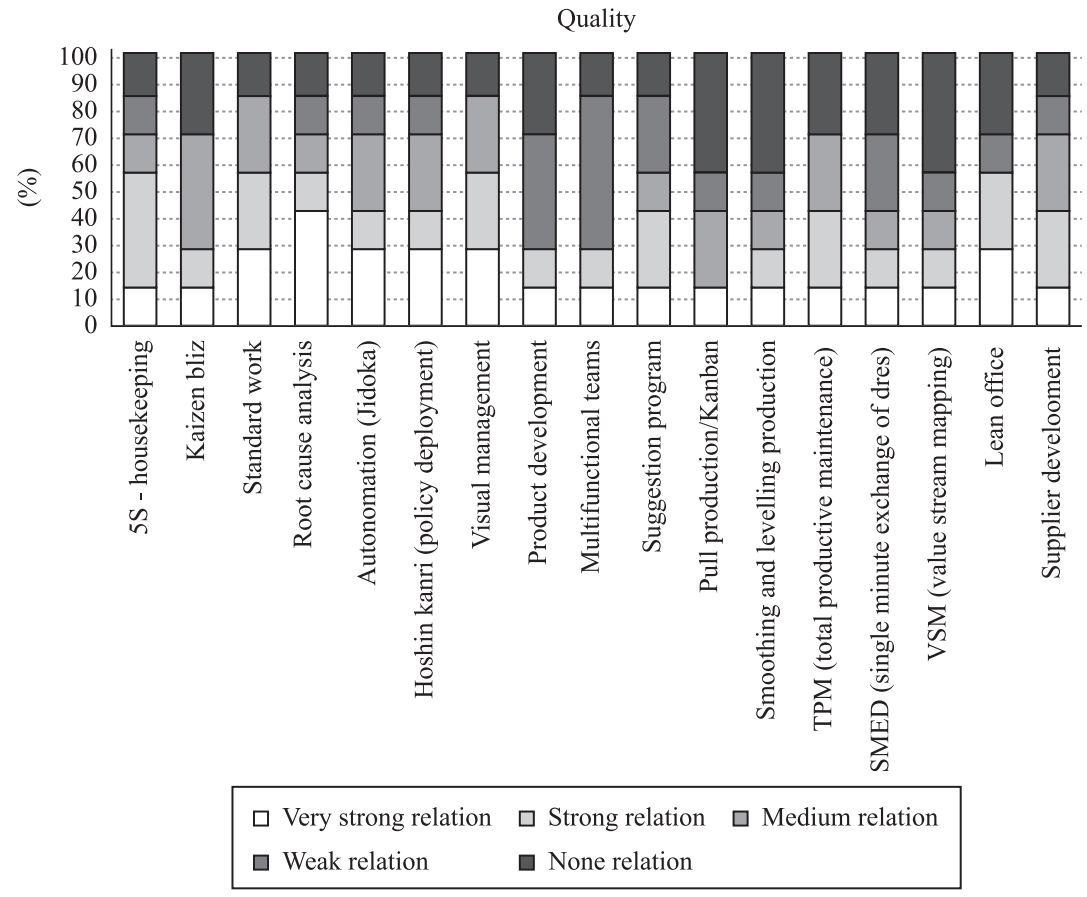

Figure 2. Relationship between lean tools and quality criteria. 


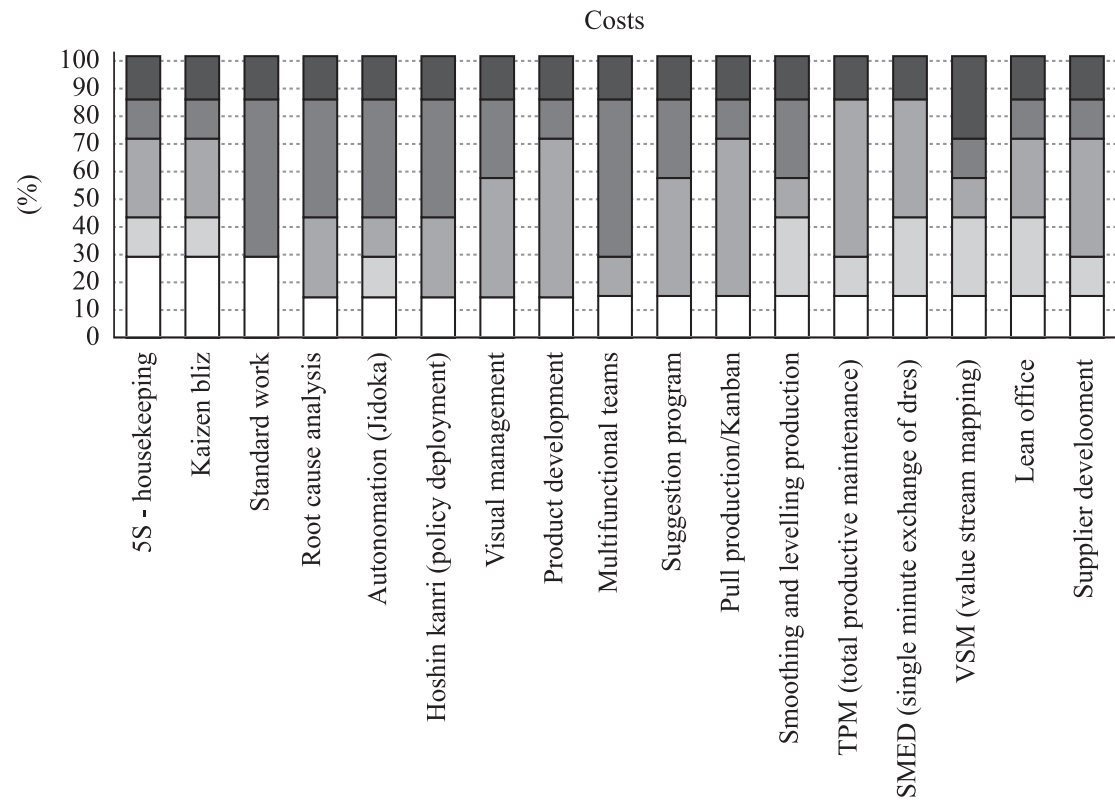

\begin{tabular}{|ll|}
\hline$\square$ Very strong relation & $\square$ Strong relation $\square$ Medium relation \\
$\square$ Weak relation & $\square$ None relation
\end{tabular}

Figure 3. Relationship between lean tools and cost criteria.

Speed

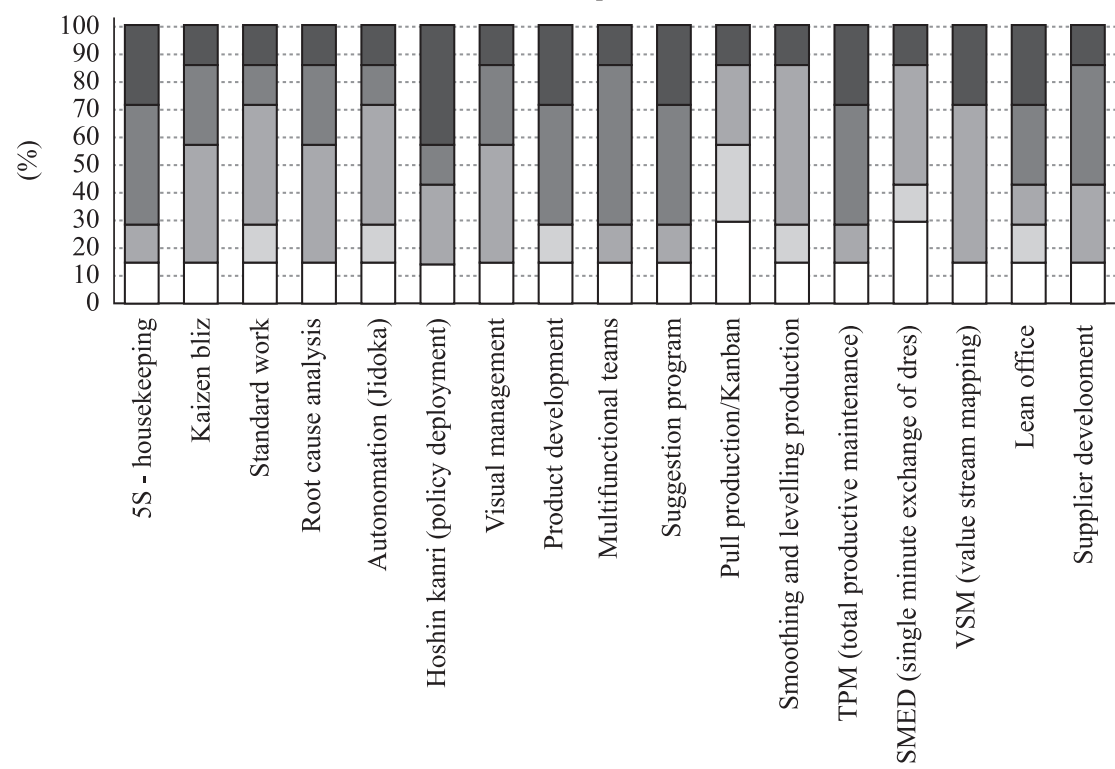

$$
\begin{array}{|ll}
\square \text { Very strong relation } & \square \text { Strong relation } \\
\square \text { Weak relation } & \square \text { Medium relation }
\end{array}
$$

Figure 4. Relationship between lean tools and speed criteria. 


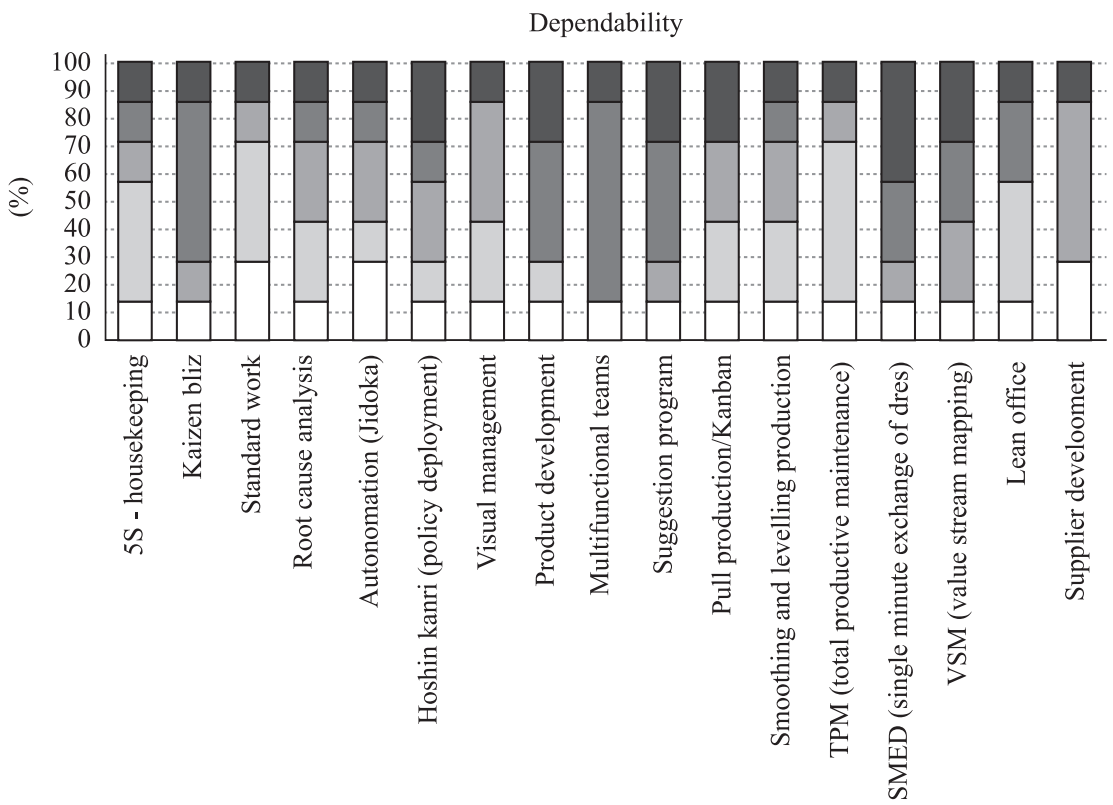

\begin{tabular}{|ll|}
\hline$\square$ Very strong relation & $\square$ Strong relation \\
$\square$ Weak relation & $\square$ Nodium relation \\
\hline
\end{tabular}

Figure 5. Relationship between lean tools and dependability criteria.

Flexibility

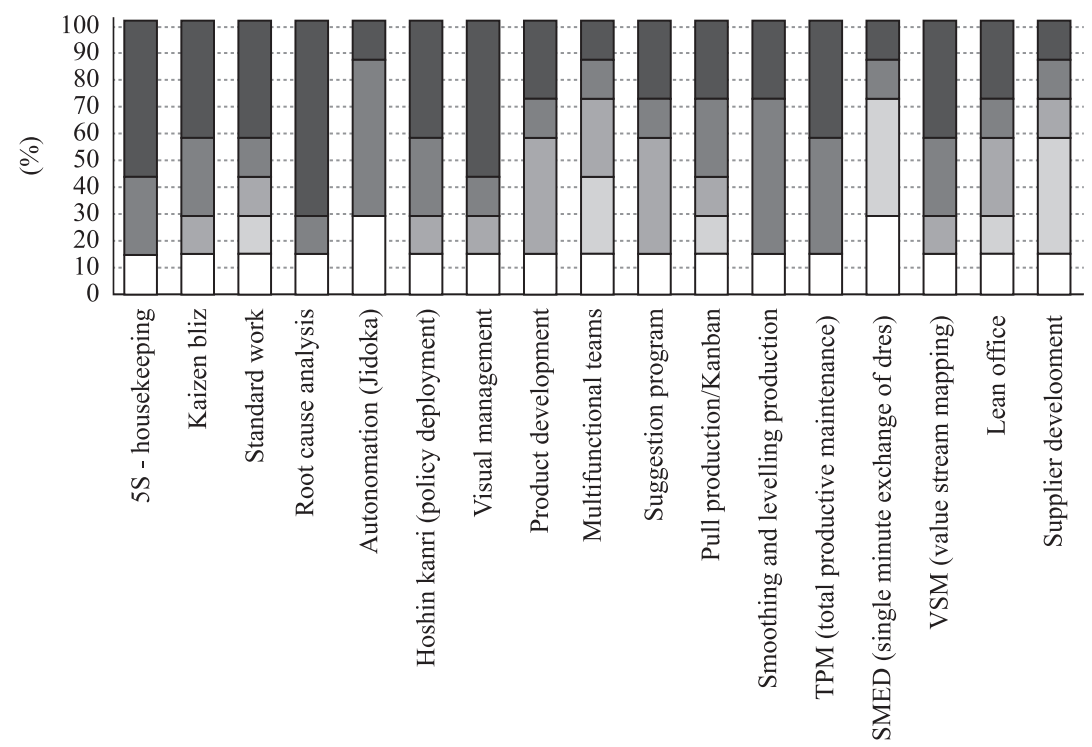

\begin{tabular}{|ll|}
\hline$\square$ Very strong relation & $\square$ Strong relation \\
$\square$ Weak relation & $\square$ Medium relation \\
\hline
\end{tabular}

Figure 6. Relationship between lean tools and flexibility criteria. 


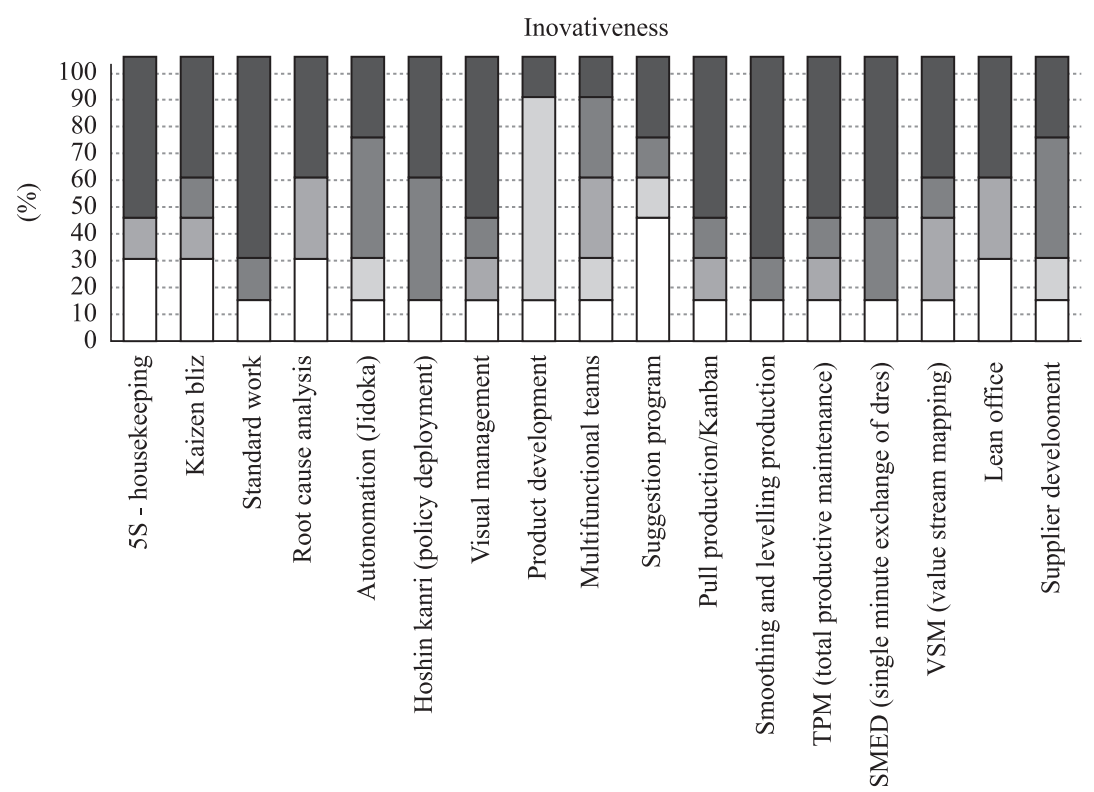

$$
\begin{array}{ll}
\square \text { Very strong relation } & \square \text { Strong relation } \quad \square \text { Medium relation } \\
\square \text { Weak relation } & \square \text { None relation }
\end{array}
$$

Figure 7. Relationship between lean tools and innovativeness criteria.

both the quality focus of lean techniques and the common quality ambition of lean implementers themselves. These two competitive dimensions were follows by costs, innovativeness, flexibility and finally speed.

The synthesis illustrated in Table 3 shows the strategic role of lean as viewed by the interviewed experts. Divergent points of view found in the literature illustrate why it has proved so difficult to precisely define how lean models affect strategy. Some interviewees considered the existence of an internal view, some of an external and others considered a mix of internal and external views. Indicative, some interviewees could not express a view so the synthesis has a few blank spaces.

On capabilities building, the common view held that lean does develop essential firm capabilities. I2 remarked that organisational learning and continuous improvement capabilities were the most important ones, as they focus on clients requirements. This was based on the logic that lean develops the ability to be always improving organisations' processes and generating learning, since there is an established focus. Meanwhile, interviewees I4, I5, I7 and I8 agreed on lean influencing continuous improvement capability. I4 proposed a waste reduction capability and I7 standardization. I5 stated that lean develops operational competence giving competence to workers being able to bring out improvements. To I6 staff skills are of primary importance and should be emphasised. I9 highlighted management leadership, problem solving and team development capabilities. I3 did not single out any specific capability, claiming that any lean initiatives that seek to improve an organisation collaborate in developing specific capabilities but contribute in developing organisational capabilities as a whole. Organisations must also ensure the balance is right between benefits and drawbacks. 
Table 3. Interviews' results.

\begin{tabular}{|c|c|c|c|}
\hline & Lean contribution on strategy & $\begin{array}{l}\text { Strategic } \\
\text { approach }\end{array}$ & Lean capabilities \\
\hline I1 & $\begin{array}{l}\text { - Lean supports any kind } \\
\text { of competitive strategy }\end{array}$ & $\begin{array}{l}\text { Internal and } \\
\text { External }\end{array}$ & $\begin{array}{c}\text { non } \\
\text { approached }\end{array}$ \\
\hline $\mathrm{I} 2$ & $\begin{array}{l}\text { - Lean supports any kind } \\
\text { of competitive strategy }\end{array}$ & External & $\begin{array}{l}\text { Continuous } \\
\text { improvement with } \\
\text { focus on client } \\
\text { requirements and } \\
\text { organisational } \\
\text { learning }\end{array}$ \\
\hline I3 & $\begin{array}{l}\text { - Lean supports some of competitive strategies } \\
\text { - Lean supports improvement on the classic } \\
\text { objectives associated to lean: costs, quality and speed. }\end{array}$ & $\begin{array}{l}\text { Internal and } \\
\text { External }\end{array}$ & non approached \\
\hline I4 & $\begin{array}{l}\text { - Lean supports some of competitive strategy } \\
\text { - Lean highly influence costs and has } \\
\text { a smaller impact on differentiation }\end{array}$ & Internal & $\begin{array}{l}\text { Waste reduction } \\
\text { and continuous } \\
\text { improvement }\end{array}$ \\
\hline I5 & $\begin{array}{l}\text { - Lean supports some of competitive strategies } \\
\text { - Lean influences directly on costs } \\
\text { - Lean influences indirectly on } \\
\text { quality and differentiation }\end{array}$ & Internal & $\begin{array}{l}\text { Operational } \\
\text { competence }\end{array}$ \\
\hline I6 & $\begin{array}{l}\text { - Lean supports some of competitive strategies } \\
\text { - Lean influences improvement on costs and } \\
\text { doesn't support differentiation based strategies }\end{array}$ & $\begin{array}{c}\text { non } \\
\text { approached }\end{array}$ & $\begin{array}{l}\text { People } \\
\text { skills }\end{array}$ \\
\hline I7 & $\begin{array}{l}\text { - Lean supports to strategy is } \\
\text { related to organizational context } \\
\text { - Lean can directly influence on quality and costs } \\
\text { - Lean can indirectly influence on others criteria }\end{array}$ & Internal & $\begin{array}{l}\text { Sustainability, } \\
\text { continuous } \\
\text { Improvement and } \\
\text { standardization }\end{array}$ \\
\hline I8 & non approached & $\begin{array}{c}\text { Internal and } \\
\text { external }\end{array}$ & $\begin{array}{l}\text { Continuous } \\
\text { improvement }\end{array}$ \\
\hline I9 & $\begin{array}{l}\text { - Lean supports any kind of competitive strategy } \\
\text { - Lean influences directly on quality, } \\
\text { speed and dependability } \\
\text { - Lean influences indirectly on costs and innovation }\end{array}$ & $\begin{array}{c}\text { Internal and } \\
\text { external }\end{array}$ & $\begin{array}{l}\text { Systemic thinking, } \\
\text { leadership, problem } \\
\text { solving and team } \\
\text { development }\end{array}$ \\
\hline
\end{tabular}

Regarding the strategic perspective of lean, I4 and I5 claimed that lean primarily acts as an internal strategic approach. In contrast, interviewee I 2 indicates that lean is more about an external view, because it is mainly about recognizing costumer value and delivering costumer requirements. Interviewees I3, I8 and I9 conciliated both these opinions, lean afford both internal and external approach. I3 considered lean as a generic receipt, which approaches both internal and external views. First, clients' requirements are considered under an external view, then resources are internally managed to deliver their required products. 
The interviews also revealed a range of opinions regarding the lean support of competitive objectives. Despite apparent similarity, they recognised direct impact on the support of costs and quality as well as in identifying costumers' value. Whether the focus is external or internal made no difference. Most of the interviewees claimed that lean can contribute to more than one market requirements simultaneously. They also agreed that lean is capable of generating key capabilities in the operations system, such as continuous improvement and organizational learning ability.

\section{Conclusion}

Lean practices and techniques are well defined in the literature, and there seems to be a consensus on their application. But the links to set capabilities have been scarcely explored. This study concludes that proposed relations of lean and operations strategy are valid in different levels of adherence. However, experts' views are still being different in some aspects.

The match between Lean techniques and set competitive priorities; some experts argued that lean can minimize trade-offs, since its application contributes to overcome contradictory criteria. There were also those who argued that lean supports only some competitive strategies. The figures that compiled all the interviews showed that different competitive priorities can be enhanced by lean tools, but this techniques influence competitive criteria in different levels.

It could be found out both streams of study in literature. Such evidence seems contradictory, but it can be complementary. Even when applying improvement programs capable to develop many performance dimensions, such dimensions should be prioritized. In order to develop operational resources accordingly, they must be focused on prioritized objectives. Additionally, results showed that lean can influence more than one competitive dimension that seems contradictory at the same time. Hence the focus of lean should be defined by organization, it's a matter of choice. Such evidence emphasizes the necessity of an operational strategy to support such a decision.

Regarding capabilities constitution when applying lean, experts pointed out a range of capabilities supported by lean which are essential to sustain a lean system. As operations strategy supports competitive dimensions as well as capabilities development, it could be conclude that lean models and operations strategy can be complementary overlapping contradictories set of arguments.

This conclusion was the basis to develop a lean strategic framework (Veiga, 2009, Veiga et al., 2009), which was applied in some case studies. Based on the framework it can be indicated some future work opportunities. The continuous necessity to have a successful lean implementation is sufficient to prove the necessity of investigation on their effects on organisational performance.

The role of trade-offs between lean and innovation models remains unsettled, since a common approach was not found in either the literature or among the experts. Many interviewees consider that lean influence on innovation is weak. However, as stated in the literature review, some authors support the existence of a strong relationship, considering innovation as a key capability of lean implementation and development. Therefore, it was pointed out the empiric study of these relationships as a future work opportunity in order to clarify this misunderstanding. 


\section{Acknowledgements}

Gabriela Lobo Veiga thanks Warwick Business School, which conferred an opportunity to carry out the research in the UK. The authors also thank the institutions whose professionals collaborated in the interviews.

\section{References}

Achanga, P.; Shehab, E.; Roy, R. and Nelder, G. (2006) Critical success factors for lean implementation within SMEs. Journal of Manufacturing Technology Management, Vol. 17, No. 4, pp. 460-471. http://dx.doi.org/10.1108/17410380610662889

Acur, N.; Gertsen, F.; Sun, H. and Frick, J. (2003) The formalisation of manufacturing strategy and its influence on the relationship between competitive objectives, improvement goals, and action plans. International Journal of Operations \& Production Management, Vol. 23, No. 10, pp. 1114-1141. http://dx.doi.org/10.1108/01443570310496599

Adler, P.S. (1993) Time and motion regained. Harvard Business Review, Vol. 71, No. 1, pp. 97-108. Reprint 93101.

Ahmed, N. and Montagno, R. (1996) Operations strategy and organizational performance: an empirical study. International Journal of Operations \& Production Management, Vol. 16, No. 5, pp. 41-53. http://dx.doi.org/10.1108/01443579610113933

Amoako-Gyampaha, K. and Boye, S.S. (2001) Operations strategy in an emerging economy: the case of the Ghanaian manufacturing industry. Journal of Operations Management, Vol. 19, pp. 59-79. http://dx.doi.org/10.1016/S0272-6963(00)00046-2

Berry, W.L.; Christiansen, T.; Bruun, P. and Ward, P. (2007) Lean manufacturing: a mapping of competitive priorities, initiatives, practices, and operational performance in danish manufacturers, in: Anais do 14 International EurOMA Conference, Ankara.

Bhasin, S. and Burcher, P. (2006) Lean viewed as a philosophy. Journal of Manufacturing Technology Management, Vol. 17, No. 1, pp. 56-72. http://dx.doi. org/10.1108/17410380610639506

Boyer, K.K. and Lewis, M.W. (2002) Competitive priorities: investing the need for trade-offs in operations strategy. Production and Operations Management, Vol. 11, No. 1, pp. 9-20. http://dx.doi.org/10.1111/j.1937-5956.2002.tb00181.x

Brown, S. and Blackmon K. (2005) Aligning manufacturing strategy and businesslevel competitive strategy in new competitive environments: the case for strategic resonance. Journal of Management Studies, Vol. 42, No. 4, pp. 793-815. http://dx.doi.org/10.1111/j.14676486.2005.00519.x

Clark, K.B. (1996) Competing through manufacturing and the new manufacturing paradigm: is manufacturing strategy passé? Production and Operations Management, Vol. 5, No. 1, pp. 42-58. http://dx.doi.org/10.1111/j.1937-5956.1996.tb00384.x

Conti, R.; Angelis, J.; Cooper, C.; Faragher, B. and Gill, C. (2006) The effects of lean production on worker job stress. International Journal of Operations \& Production Management, Vol. 26, No. 9, pp.1013-1038. http://dx.doi.org/10.1108/01443570610682616

Corbett, L. M. and Campbell-Hunt, C. (2002) Grappling with a gusher! Manufacturing's response to business success in small and medium enterprises. Journal of Operations Management, Vol. 20, No. 5, pp. 495-517. http://dx.doi.org/10.1016/S02726963(02)00026-8

Dahlgaard, J.J. and Dahlgaard-Park, S.M. (2006) Lean production, six sigma quality, TQM and company Culture. The TQM Magazine, Vol. 18, No. 3, pp. 263-281. http://dx.doi. org/10.1108/09544780610659998 
De Toni, A. and Tonchia, S. (2002) New production models: a strategic view. International Journal of Production Research, Vol. 40, No. 18, pp. 4721-4741. http://dx.doi. org/10.1080/00207540210158005

Fishman, C. (2007) No Satisfaction. HSM Management, Vol. 3, No. 62, pp. 46-52.

Flynn, B.; Schroeder, R. and Flynn, J. (1999) World class manufacturing: an investigation of Hayes and Wheelwright's foundation. Journal of Operations Management, Vol. 17, No. 3, pp. 249-269. http://dx.doi.org/10.1016/S0272-6963(98)00050-3

Hayes, R. and Pisano, G. (1994) Beyond world-class: the new manufacturing strategy. Harvard Business Review, Vol. 72, No. 1, pp.77-86.

Hayes, R. and Wheelwright, S. (1985) Restoring Our Competitive Edge: Competing through manufacturing. Harvard Business Review, Vol. 47, No. 3, pp. 99-109.

Holweg, M. (2006) The genealogy of lean production. Journal of Operations Management, Vol. 25, No. 2, pp. 420-437. http://dx.doi.org/10.1016/j.jom.2006.04.001

Katayama, H. and Bennett, D. (1999) Agility, adaptability and leanness: A comparison of concepts and a study of practice. International Journal of Production Economics, Vol. 60-61, pp. 43-51. http://dx.doi.org/10.1016/S0925-5273(98)00129-7

Laugen, B.; Boer, H.; Acur, N. and Frick, J. (2005) Best manufacturing practices: What do the Best-performing companies do? International Journal of Operations \& Production Management, Vol. 26, No. 2, pp. 131-150. http://dx.doi.org/10.1108/01443570510577001

Leong, G.K.; Snyder, D.L. and Ward, P.T. (1990) Research in the process and contend of manufacturing strategy. OMEGA International Journal of Management Science, Vol. 18, No. 2, pp. 109-122. http://dx.doi.org/10.1016/0305-0483(90)90058-H

Leong, G.K.; Ward, P.T. (1995) The six Ps of manufacturing Strategy. International Journal of Operations \& Production Management, Vol. 15, No. 12, pp. 32-45. http://dx.doi. org/10.1108/01443579510104484

Lewis, M. and Slack, N. (2002) Operations strategy (US edition). Prentice-Hall: Harlow. PMCid:1422589

Lewis, M.A. (2000) Lean production and sustainable competitive advantage. International Journal of Operations \& Production Management, Vol. 20, No. 8, pp. 959-978. http://dx.doi.org/10.1108/01443570010332971

Liker, J.K. (2006) O modelo Toyota, 14 princípios de gestão do maior fabricante do mundo. Porto Alegre: Bookman. (in Protuguese)

May, M.E. (2007) The elegant solution: Toyota's formula for mastering innovation. New York: Free Press.

Narasimham, R.; Swink, M. and Kim, S.W. (2006) Disentangling Leaness and agility: an empirical investigation. Journal of Operations Management, Vol. 24, No. 5, pp. 440-457. http://dx.doi.org/10.1016/j.jom.2005.11.011

Naylor, J.B.; Naim, M.M. and Berry, D. (1999) Leagility: Integrating the lean and agile manufacturing paradigms in the total supply chain. International Journal of Production Economics, Vol. 62, pp. 107-118. http://dx.doi.org/10.1016/S0925-5273(98)00223-0

Nonaka, I. and Takeuchi, H. (1997) Criação de conhecimento na empresa: como as empresas Japonesas geram a Dinâmica da Inovação. Rio de Janeiro: Editora Campus. (in Protuguese)

Ohno, T. (1997) O sistema Toyota de produção além da produção em larga escala. Porto Alegre: Bookman. (in Protuguese)

Organização para a Cooperação e Desenvolvimento Econômico - OCDE (1997) Manual de Oslo: diretrizes para a coleta e interpretação de dados sobre inovação. 3 ed. (in Protuguese) 
Platts, K. and Gregory, M. (1990) Manufacturing audit in the process of strategy formulation. International Journal of Operations \& Production Management, Vol. 10, No. 9, pp. 5-26. http://dx.doi.org/10.1108/EUM0000000001264

78.

Porter, M. (1996) What's strategy? Harvard Business Review, Vol. 74, No. 6, pp. 61-

Rea, L. and Parker, R. (2002) Metodologia de pesquisa: do planejamento à execução. São Paulo: Pioneira Thompson Learning. (in Protuguese)

Sánchez, A.M. and Pérez, M.P. (2001) Lean indicators and manufacturing strategies. International Journal of Operations Management, Vol. 21, No. 11, pp. 1433-1451. http://dx.doi. org/10.1108/01443570110407436

Saurin, T.A. and Ferreira, C.F. (2009) The impacts of lean production on working conditions: A case study of a harvester assembly line in Brazil. International Journal of Industrial Ergonomics, Vol. 39, No. 2, pp. 403-412. http://dx.doi.org/10.1016/j.ergon.2008.08.003

Schonberger, R.J. (2007) Japanese production management: an evolution-with mixed success. Journal of Operations Management, Vol. 25, No. 2, pp. 403-419. http://dx.doi. org/10.1016/j.jom.2006.04.003

Shah, R. and Ward, P.T. (2003) Lean manufacturing: context, practice bundles, and performance. Journal of Operations Management, Vol. 21, pp. 129-149. http://dx.doi.org/10.1016/ S0272-6963(02)00108-0

Silveira, G.J.C. (2005) Improving trade-offs in manufacturing: method and illustration. International Journal of Production Economics, Vol. 95, pp. 27-38. http://dx.doi. org/10.1016/j.ijpe.2003.10.023

Sim, K.L. and Rogers, J.W. (2009) Implementing lean production systems: barriers to change. Management Research News, Vol. 32, No. 1, pp. 37-49. http://dx.doi. org/10.1108/01409170910922014 pp. 113-121.

Skinner, W. (1974) The focused factory. Harvard Business Review, Vol. 52, No. 3,

Slack, N. (1993) Vantagem competitiva em manufatura: atingindo competitividade nas operações industriais. São Paulo: Atlas. (in Protuguese)

Slack, N. (2005) Operations strategy: will it ever realize its potential? Gestão \& Produção, Vol. 12, No. 3, pp. 323-332. http://dx.doi.org/10.1590/S0104-530X2005000300004

Slack, N.; Chambers, S.; Harland, C.; Harrison, A. and Johnston, R. (1997) Administração da produção. São Paulo: Atlas. (in Portuguese)

Smeds, R. (1994) Managing change towards lean enterprises. International Journal of Operations \& Production Management, Vol. 14, No. 3, pp. 66-82. http://dx.doi. org/10.1108/01443579410058531

Smith, T.M. and Reece, J.S. (1999) The relationship of strategy, fit, productivity, and business performance in a services setting. Journal of Operations Management, Vol. 17, No. 2, pp. 145-61. http://dx.doi.org/10.1016/S0272-6963(98)00037-0

Spear, J.S. (2004) Learning to Lead at Toyota. Harvard Business Review, Vol. 82, No. 4, pp. 78-86.

Spear, S.; Bowen, H. (1999) Decoding the DNA of the Toyota Production System. Harvard Business Review, Vol. 77, No. 5, pp. 96-106.

Steward, T.A. and Raman, A.P. (2007) Lessons from Toyota Long Way. Harvard Business Review, Vol. 85, No.7/8, pp. 74-83.

Sun, H. and Hong, C. (2002) The alignment between manufacturing and business strategies: is influence on business performance. Technovation, Vol. 22, No. 1, pp. 699-705. http://dx.doi.org/10.1016/S0166-4972(01)00066-9 
Sweeney, M.T. (1991) Towards a unified theory of strategic manufacturing management. International Journal of Operations \& Production Management, Vol. 11, No. 5, pp. 6-22. http://dx.doi.org/10.1108/EUM0000000001277

Takeuchi, H.; Osono, E. and Shimizu, N. (2008) Contradictions that drive Toyota's Success. Harvard Business Review, Vol. 86, No. 6, pp. 96-104.

Thun, J. (2008) Empirical analysis of manufacturing strategy implementation. International Journal of Production Economics, Vol. 113 No. 1, pp. 370-382. http://dx.doi. org/10.1016/j.ijpe.2007.09.005

Towill, DR.; Zhou, L. and Disney, SM. (2007) Reducing the bullwhip effect: Looking through the appropriate lens. International Journal of Production Economics, Vol. 108, No. 1-2, pp. 444-453. http://dx.doi.org/10.1016/j.ijpe.2006.12.024

Veiga, G.L. (2009) Uma discussão sobre o papel estratégico do modelo de produção enxuta. Dissertação. Programa de Pós-Graduação em Engenharia de Produção e Sistemas, Pontifícia Universidade Católica do Paraná, Curitiba, Brasil. (in Protuguese)

Veiga, G.L.; Pinheiro de Lima, E.; Angelis, J.J. and Gouvea da Costa, S.E. (2009) Lean manufacturing strategic role: a case study, in: 15th International Annual EurOMA Conference, Göteborg.

Wernerfelt, B. (1984) A resource-based view of the firm. Strategic Management Journal, Vol. 5, No. 2, pp. 171-180. http://dx.doi.org/10.1002/smj.4250050207

Womack, J.P; Jones, D.T. and Roos, D. (1996) A máquina que mudou o mundo. Rio de Janeiro: Campus. (in Protuguese)

Yeung, A.C.L.; Lai, K. and Yee, R.W.Y. (2007) Organizational learning, Innovativeness, and organizational performance: a qualitative investigation. International Journal of Production Research, Vol. 45, No. 11, pp. 2459 -2477. http://dx.doi.org/10.1080/00207540601020460

Yin, R.K. (2001) Estudo de caso: planejamento e métodos. 2 ed. Porto Alegre: Bookman. (in Protuguese)

\section{Biography}

Gabriela L. Veiga is a consultant at Gestão Inteligente Consultoria Empresarial (Enterprise Consultancy), Curitiba, Brazil. She holds a BSc Degree in Industrial Engineering (PUCPR) and a MSc degree in Industrial and System Engineering (PUCPR). Her professional activities are related to Toyota Production System implementation, strategic planning development and improvement quality processes.

Contact: gabriela@gestaointeligente.com

Edson Pinheiro de Lima is a founder member of the Mechatronics and Industrial Engineering group at the Pontifical Catholic University of Parana - PUCPR, Brazil. He is also an Associate Professor at Federal University of Technology - Paraná (UTFPR), Brazil. He has a research productivity scholarship from CNPq. He was a Visiting Research Fellow at the Operations Management Group of Warwick Business School at University of Warwick, UK. He holds a BSc Degree in Electrical Engineering (UTFPR), a MSc Degree in Electrical Engineering - Automation (UNICAMP) and a $\mathrm{PhD}$ in Industrial Engineering (UFSC). His research and teaching is in the operations strategy, performance management, strategic management and organisational design.

Contact: e.pinheiro@pucpr.br 
Jannis J. Angelis is an Assistant Professor in the Operations Management Group of the Warwick Business School at University of Warwick, UK. He holds a BA Degree in Economics and Economic History (Lund and Stockholm Universities), a BA Degree in Philosophy (Stockholm University), a BSocSc Degree in Political Science (Uppsala and Stockholm Universities), a MSocSc Degree in International Relations (Stockholm University), a MA Degree in China Studies (SOAS, London), MPhil Degree in Industrial Relations (Cambridge), PGCPCE (HE) Diploma (University of Warwick) and a PhD Degree in Management (Judge Business School, Cambridge). His research and teaching is in operations strategy, lean and agile operations, behavioural operations, supply chain sustainability and health service improvements.

Contact: Jannis.Angelis@wbs.ac.uk

Sergio E. Gouvêa da Costa is a founder member of the Mechatronics and Industrial Engineering group at the Pontifical Catholic University of Paraná - PUCPR, Brazil. He is also an Associate Professor at Federal University of Technology - Paraná (UTFPR), Brazil. He has a research productivity scholarship from CNPq. He was a Visiting Professor at the Edward P. Fitts Department of Industrial and Systems Engineering at North Carolina State University (NCSU, USA) from July 2009 to July 2010. He holds a BSc Degree in Electrical Engineering (UTFPR), a MSc Degree in Electrical Engineering - Automation (UNICAMP) and a PhD in Industrial Engineering (USP). His research and teaching is in manufacturing strategy and performance area, AMT adoption and technology management.

Contact: s.gouvea@pucpr.br

\section{Article Info:}

Received: March, 2010

Accepted: May, 2011 
